\title{
Revision of the Phase Equilibrium Diagram of the Binary System Calcia-Titania, Showing the Compound $\mathrm{Ca}_{4} \mathrm{Ti}_{3} \mathrm{O}_{10}$
}

\author{
Robert S. Roth
}

\begin{abstract}
The compound $\mathrm{Ca}_{4} \mathrm{Ti}_{3} \mathrm{O}_{10}$ has been found to be a stable phase in the system $\mathrm{CaO}-\mathrm{TiO}_{2}$. It melts incongruently at about $1755 \pm 10^{\circ} \mathrm{C}$, presumably to $\mathrm{CaTiO}_{3}$ plus liquid. This compound is shown in a revision of the phase diagram for the system $\mathrm{CaO}-\mathrm{TiO}_{2}$.
\end{abstract}

\section{Introduction}

Phase equilibrium diagrams for the system $\mathrm{CaO}$ $\mathrm{TiO}_{2}$ were published almost simultaneously by Coughanour, Roth, and DeProsse $[1]^{1}$ and by DeVries, Roy, and Osborn [2]. The diagrams are very similar, both showing the existence of two compounds, $\mathrm{CaTiO}_{3}$ and $\mathrm{Ca}_{3} \mathrm{Ti}_{2} \mathrm{O}_{7}$. DeVries et al. [2], discussed the reactions between the two compounds and, on the basis of some changes in the X-ray patterns of the mixtures, concluded that a small amount of solid solution existed in both compounds. They published an X-ray pattern of $\mathrm{Ca}_{3} \mathrm{Ti}_{2} \mathrm{O}_{7}$ which was quite similar to that reported by Fisk [3] for the same compound. Coughanour, Roth, and DeProsse [1] did not find solid solution between the two compounds but reported an X-ray pattern for $\mathrm{Ca}_{3} \mathrm{Ti}_{2} \mathrm{O}_{7}$ which contained many more lines than those of the other publications.

Ruddlesden and Popper [4] studied the compound $\mathrm{Sr}_{3} \mathrm{Ti}_{2} \mathrm{O}_{7}$ and have indicated it to be body centered tetragonal with $a=3.90 \mathrm{~A}$ and $c=20.38 \mathrm{~A}$. They have also found a compound $\mathrm{Sr}_{2} \mathrm{TiO}_{4}[5]$ which contains alternate layers of perovskite and $\mathrm{SrO}$, and have proposed that $\mathrm{Sr}_{3} \mathrm{Ti}_{2} \mathrm{O}_{7}$ contains double perovskite layers interleaved with one SrO layer.

\section{X-Ray Diffraction Data}

The X-ray pattern previously published by Coughanour, Roth, and DeProsse [1] for $\mathrm{Ca}_{3} \mathrm{Ti}_{2} \mathrm{O}_{7}$ can be partially accounted for on the basis of a body centered tetragonal cell with $a=3.832 \mathrm{~A}$ and $c=19.505$ A. The pattern published by DeVries, Roy, and Osborn [2], which contains fewer lines, can be almost completely accounted for by a body centered tetragonal unit cell with $a=3.8 \AA \mathrm{A}$ and $c=19.5 \mathrm{~A}$. These values correspond to double perovskite layers interleaved with $\mathrm{CaO}$ layers.

In the $\mathrm{SrO}-\mathrm{TiO}_{2}$ system Ruddlesden and Popper [4] predicted the possible existence of phases with triple or quadruple perovskite layers interleaved with $\mathrm{SrO}$ layers. They found some evidence for a compound $\mathrm{Sr}_{4}{ }^{T} \mathrm{Ti}_{3} \mathrm{O}_{10}$, which is also body centered tetragonal, with $a=3.90 \mathrm{~A}$ and $c=28.1 \mathrm{~A}$, and contains triple perovskite layers.

Many of the extra lines in the pattern of Coughanour, Roth, and DeProsse [1] ${ }^{2}$ can be accounted

1 Figures in brackets indicate literature references at the end of this paper. 2 This pattern is represented in the ASTM index of X-ray diffraction powder patterns by card No. 6-0698. As this pattern is a mixture of two compounds it should be eliminated and replaced by the two patterns listed in this paper.

for by assuming a mixture of two body centered tetragonal compounds, $\mathrm{Ca}_{3} \mathrm{Ti}_{2} \mathrm{O}_{7}$ and $\mathrm{Ca}_{4} \mathrm{Ti}_{3} \mathrm{O}_{10}$, the latter having a $c$-axis of $27.147 \mathrm{~A}$. In the present study the two compounds have been isolated and the partially indexed X-ray patterns of both compounds are shown in tables 1 and 2. Although these two

TABLE 1. X-ray diffraction powder pattern for the compound $\mathrm{Ca}_{3} \mathrm{Ti}_{2} \mathrm{O}_{7}$ (CuK $\mathrm{Cu}_{\alpha 1}$ radiation)

\begin{tabular}{|c|c|c|c|c|c|c|}
\hline \multirow{2}{*}{$\begin{array}{c}\text { Fisk } \\
\qquad d\end{array}$} & \multirow{2}{*}{$\begin{array}{c}\text { DeVries, } \\
\text { Roy, } \\
\text { Osborn }\end{array}$} & \multicolumn{4}{|c|}{ Present work } & \multirow{2}{*}{$h k l$} \\
\hline & & $d_{\text {obs }}$ & $I / I_{0}$ & $1 / d^{2}$ obs & $1 / d^{2} \mathrm{eal}^{\mathrm{a}}$ & \\
\hline$(4.88)$ & $\begin{array}{l}9.77 \\
4.887 \\
3.762 \\
- \\
\end{array}$ & $\begin{array}{l}9.73 \\
4.873 \\
3.762 \\
3.302 \\
\end{array}$ & $\begin{array}{r}\text { b } 100 \\
\text { b } 100 \\
8 \\
3 \\
-\end{array}$ & $\begin{array}{r}0.0106 \\
.0421 \\
.0707 \\
.0907 \\
.\end{array}$ & $\begin{array}{r}0.0105 \\
.0421 \\
.0707 \\
.0918 \\
.0946\end{array}$ & $\begin{array}{l}002 \\
004 \\
101 \\
103 \\
006\end{array}$ \\
\hline 2.70 & $\begin{array}{r}2.730 \\
2.710 \\
-\end{array}$ & $\begin{array}{l}2.733 \\
2.708 \\
\end{array}$ & $\begin{array}{r}100 \\
66 \\
\end{array}$ & $\begin{array}{r}.1339 \\
.1364 \\
\end{array}$ & $\begin{array}{l}.1338 \\
.1362 \\
.1467\end{array}$ & $\begin{array}{l}105 \\
110 \\
112\end{array}$ \\
\hline 2.51 & 2.481 & $\begin{array}{l}2.478 \\
2.439\end{array}$ & ь 7 & $\begin{array}{l}.1629 \\
.1681\end{array}$ & .1682 & 008 \\
\hline $\begin{array}{l}2.19 \\
1.93 \\
1.91 \\
\end{array}$ & $\left\{\begin{array}{l}2.254 \\
2.080 \\
1.9509 \\
1.9141 \\
1.8860\end{array}\right.$ & $\begin{array}{l}2.255 \\
2.081 \\
1.9505 \\
1.9159 \\
1.8871\end{array}$ & $\begin{array}{r}11 \\
23 \\
\text { в } 100 \\
27 \\
14\end{array}$ & $\begin{array}{l}.1967 \\
.2308 \\
.2629 \\
.2724 \\
.2808\end{array}$ & $\begin{array}{l}.1783 \\
.1969 \\
.2308 \\
.2629 \\
.2724 \\
.2810\end{array}$ & $\begin{array}{r}114 \\
107 \\
116 \\
0 \cdot 0 \cdot 10 \\
200 \\
109\end{array}$ \\
\hline 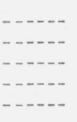 & מ & $\begin{array}{l}1.7836 \\
1.7363 \\
1.7080\end{array}$ & $\begin{array}{l}-1 \\
6 \\
3 \\
3\end{array}$ & $\begin{array}{l}.3143 \\
.3317 \\
.3428\end{array}$ & $\begin{array}{r}.2829 \\
.3044 \\
.3145 \\
-.3432\end{array}$ & $\begin{array}{r}202 \\
118 \\
204 \\
211\end{array}$ \\
\hline $\begin{array}{l}1.57 \\
-1 .\end{array}$ & $\left\{\begin{array}{r}1.5826 \\
1.5679\end{array}\right.$ & $\begin{array}{l}1.6581 \\
1.6258 \\
\text { 1. } 5831 \\
1.5690\end{array}$ & $\begin{array}{c}4 \\
\text { b } 37 \\
38 \\
27\end{array}$ & $\begin{array}{r}.3637 \\
-.3783 \\
-.3990 \\
.4062\end{array}$ & $\begin{array}{r}.3642 \\
.3671 \\
.3785 \\
.3862 \\
3991 \\
.4062\end{array}$ & $\begin{array}{r}213 \\
206 \\
0 \cdot 0 \cdot 12 \\
1 \cdot 0 \cdot 11 \\
1 \cdot 1 \cdot 10 \\
215\end{array}$ \\
\hline 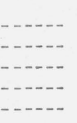 & 1. 3912 & $\begin{array}{l}1.4598 \\
1.3933\end{array}$ & b & 0.4693 & $\begin{array}{r}0.4406 \\
.4693 \\
.5123 \\
.5147 \\
.5152\end{array}$ & $\begin{array}{r}208 \\
217 \\
1 \cdot 0 \cdot 13 \\
1 \cdot 1 \cdot 12 \\
0 \cdot 0 \cdot 14\end{array}$ \\
\hline 1.358 & $\begin{array}{r}1.3662 \\
1.3423\end{array}$ & $\begin{array}{l}\text { 1. } 3667 \\
\text { 1. } 3539 \\
1.3444 \\
\\
\end{array}$ & $\begin{array}{r}14 \\
10 \\
5 \\
- \\
---\end{array}$ & $\begin{array}{r}.5354 \\
.5455 \\
.5533 \\
-.--- \\
----\end{array}$ & $\begin{array}{l}.5353 \\
.5448 \\
.5534 \\
.5554 \\
.5869\end{array}$ & $\begin{array}{r}2 \cdot 0 \cdot 10 \\
220 \\
219 \\
222 \\
224\end{array}$ \\
\hline 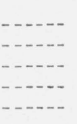 & P. & 1. 2394 & $\begin{array}{c}-\cdots \\
-\cdots \\
-\cdots\end{array}$ & .6510 & $\begin{array}{l}.6156 \\
.6366 \\
.6395 \\
.6509 \\
.6514\end{array}$ & $\begin{array}{r}301 \\
303 \\
226 \\
2 \cdot 0 \cdot 12 \\
1 \cdot 1 \cdot 14\end{array}$ \\
\hline - - & 1. 2303 & 1. 2318 & 5 & .6591 & $\left\{\begin{array}{l}.6586 \\
.6595\end{array}\right.$ & $\begin{array}{l}2 \cdot 1 \cdot 11 \\
1 \cdot 0 \cdot 15\end{array}$ \\
\hline - n... & - n- & 1.2191 & b 15 & .6729 & $\begin{array}{r}6729 \\
6787\end{array}$ & $\begin{array}{r}0 \cdot 0 \cdot 16 \\
305\end{array}$ \\
\hline 1.210 & 1.2119 & 1. 2109 & 4 & .6819 & .6811 & $\begin{array}{l}310 \\
312\end{array}$ \\
\hline - - & & - - n- & & - & .6916 & 208 \\
\hline 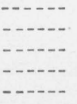 & - & - & - & - & $\begin{array}{l}.7101 \\
.7231 \\
.7417 \\
.7757 \\
.7847\end{array}$ & $\begin{array}{r}314 \\
307 \\
316 \\
2 \cdot 1 \cdot 13\end{array}$ \\
\hline
\end{tabular}


TABLE 1. X-ray diffraction powder pattern for the compound $\mathrm{Ca}_{3} \mathrm{Ti}_{2} \mathrm{O}_{7}\left(\mathrm{CuK}_{\alpha 1}\right.$ radiation $)$ - Continued

\begin{tabular}{|c|c|c|c|c|c|c|}
\hline \multirow{2}{*}{$\begin{array}{c}\text { Fisk } \\
d\end{array}$} & \multirow{2}{*}{$\begin{array}{c}\begin{array}{c}\text { DeVries, } \\
\text { Roy, } \\
\text { Osborn }\end{array} \\
d\end{array}$} & \multicolumn{4}{|c|}{ Present work } & \multirow{2}{*}{$h k l$} \\
\hline & & $d_{\text {obs }}$ & $I / I_{0}$ & $1 / d^{2}$ obs & $1 / d^{2}{ }_{\mathrm{eal}}{ }^{\mathrm{a}}$ & \\
\hline & - & 1.1234 & 2 & 7924 & .7876 & $2 \cdot 0 \cdot 14$ \\
\hline & - & 1. 1124 & 4 & .8081 & .8077 & $2 \cdot 2 \cdot 10$ \\
\hline -..... & -....- & -...- & --- & - & 0.8091 & $1 \cdot 1 \cdot 16$ \\
\hline - & - & 1.0995 & 4 & .8272 & $\begin{array}{l}.8209 \\
.8277\end{array}$ & $\begin{array}{r}309 \\
1.0 \cdot 17\end{array}$ \\
\hline---- & - & ----- & -..- & -..-. & .8493 & $\begin{array}{r}318 \\
0.0 .18\end{array}$ \\
\hline 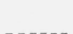 & & & & & seen & \\
\hline---- & - & 1.0559 & 9 & .8969 & .8880 & 321 \\
\hline - & - - - & - & 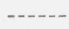 & - & .9090 & 323 \\
\hline$\ldots$ & -.... & -... & 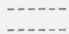 & - & $\begin{array}{l}.9233 \\
.9310\end{array}$ & $\begin{array}{l}2 \cdot 2 \cdot 12 \\
3 \cdot 0 \cdot 11\end{array}$ \\
\hline & & & & & .9319 & $2 \cdot 1 \cdot 15$ \\
\hline-- & 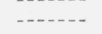 & 1. 0292 & 6 & .9441 & .9439 & $3 \cdot 1 \cdot 10$ \\
\hline 1.021 & - & 1. 0251 & 4 & .9516 & $\begin{array}{l}.9453 \\
.9511\end{array}$ & $\begin{array}{r}2 \cdot 0 \cdot 16 \\
325\end{array}$ \\
\hline$\ldots$ & -..--- & $\cdots$ & & ----- & .9878 & $1 \cdot 1 \cdot 18$ \\
\hline - & - - & & & & 1. 0142 & 327 \\
\hline-- & - - & 0.99168 & 10 & 1. 0168 & 1. 0170 & $\begin{array}{l}1 \cdot 0 \cdot 19 \\
0.00\end{array}$ \\
\hline ---N- & - & - . & & $\begin{array}{l}1.0512 \\
-.-.-\end{array}$ & $\begin{array}{l}\text { 1. } 0514 \\
\text { 1. } 0572\end{array}$ & $\begin{array}{l}0.0 \cdot 20 \\
3 \cdot 0 \cdot 13\end{array}$ \\
\hline - & - & - & --.-- & - & 1. 0596 & $3 \cdot 1 \cdot 12$ \\
\hline-- & -...-. & & & & 1. 0600 & $2 \cdot 2 \cdot 14$ \\
\hline -...- & - & .95764 & 2 & 1. 0904 & 1. 0897 & 400 \\
\hline .. & -...-..-. & .95359 & 3 & 1. 0997 & $\begin{array}{l}1.0980 \\
1.1002\end{array}$ & $2 \cdot 1 \cdot 17$ \\
\hline & & -..- & & & $\begin{array}{l}\text { 1. } 1002 \\
\text { 1. } 1241\end{array}$ & $\begin{array}{r}402 \\
2.0 \cdot 18\end{array}$ \\
\hline &.- & - & & - & 1.1317 & 404 \\
\hline & & ... & & -..-. & 1. 1604 & 411 \\
\hline - & --.- & --.-- & ---- & - & 1. 1814 & 413 \\
\hline$\ldots$ & - & 0.91768 & 7 & 1.1875 & $\begin{array}{l}1.1843 \\
1.1876\end{array}$ & $\begin{array}{r}406 \\
4\end{array}$ \\
\hline - & -..--..- & --.-- & ---.- & -.--- & 1. 1962 & $3 \cdot 1 \cdot 14$ \\
\hline$\cdots$ & - & & & & 1. 2034 & $3 \cdot 2 \cdot 11$ \\
\hline -..... & --.---. & .91125 & 5 & 1. 2043 & 1. 2044 & $\begin{array}{r}0.15 \\
0.15\end{array}$ \\
\hline - n-n & -....... & - & -1- & - & 1. 2235 & 415 \\
\hline-- & ----s- & .90346 & 6 & 1. 2251 & 1. 2259 & 330 \\
\hline - - & --_--.-- & .90236 & 11 & 1. 2281 & 1. 2273 & $1 \cdot 0.21$ \\
\hline - - & -....- & - & ---- & - & 1. & 332 \\
\hline - & 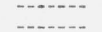 & -...- & -...... & ........ & $\begin{array}{l}1.2579 \\
1.2680\end{array}$ & $\begin{array}{l}408 \\
334\end{array}$ \\
\hline - - & - & .88673 & b 43 & 1.2718 & 1. 2722 & $0 \cdot 0.22$ \\
\hline - & $\ldots$ & & 8 & & 1. 2866 & 417 \\
\hline 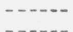 & ---- & .88058 & 8 & 1.2896 & 1. 2 & $2 \cdot 1 \cdot 19$ \\
\hline & - & .86915 & 4 & 1.3238 & 1.3238 & $2 \cdot 0 \cdot 20$ \\
\hline- & --.-. & - & ----- & - - & 1. 3296 & $3 \cdot 2 \cdot 13$ \\
\hline -.--.- & -. & .85982 & 5 & 1.3526 & 1. 3525 & $4 \cdot 0 \cdot 10$ \\
\hline- & $-\cdots$ & ------ & 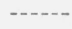 & $\ldots$ & 1. 3540 & $3 \cdot 1 \cdot 16$ \\
\hline- & - & - & 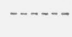 & --- & 1. 3621 & $\begin{array}{l}420 \\
419\end{array}$ \\
\hline --.-.- & --.--.- & .85388 & 4 & 1.3715 & $\begin{array}{l}\text { 1. } 37266 \\
1.3726\end{array}$ & 3.0.17 \\
\hline - & - - & ---N- & -..- & - & 1. 3919 & $2 \cdot 1 \cdot 20$ \\
\hline -----. & $\ldots$ & - & -...... & ..... & 1. 3941 & 338 \\
\hline- & $-\cdots-\cdot$ & ----- & $\ldots$ & $-\cdots$ & & $2 \cdot 2 \cdot 18$ \\
\hline- & - & .84268 & 5 & 1.4082 & $\begin{array}{l}1.4042 \\
1.4084\end{array}$ & $\begin{array}{c}424 \\
1 \cdot 1 \cdot 22\end{array}$ \\
\hline-- & -- & - & $-\cdots-$ & - & 1.4567 & 426 \\
\hline --.-- & --.---- & -..--.- & -..-..- & ----.. & 1. 4586 & 1.0 .23 \\
\hline & & & & & 82 & $\cdot 0 \cdot 12$ \\
\hline$\cdots$ & --s-u- & --.-- & $\cdots$ & --- & & 4.1 \\
\hline 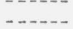 & - & 0.81968 & 4 & 1.4884 & 1. 4887 & $\begin{array}{l}3 \cdot 2 \cdot 15 \\
3 \cdot 3 \cdot 10\end{array}$ \\
\hline 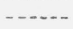 & - & .81272 & b 22 & 1.5140 & 1.5140 & 0.0 .24 \\
\hline$\cdots$ & - & -- & ----.- & $\cdots$ & 1.5303 & 428 \\
\hline$\ldots$ & --. & & & & 1. 5327 & $3 \cdot 1 \cdot 18$ \\
\hline -.. & --.-- & .80463 & 5 & 1.5446 & & 2.0 .22 \\
\hline & 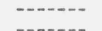 & -....... & 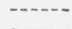 & 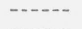 & 1. 5618 & 3.0.19 \\
\hline & & & & ....... & 1.5962 & $2 \cdot 2 \cdot 20$ \\
\hline
\end{tabular}

a The $1 / d^{2}$ values have been calculated on the basis of a tetragonal unit cell

with $a=3.832 \mathrm{~A}, c=19.505 \mathrm{~A}$.
b These (oo1) peaks are probably abnormally strong due to preferred orientation.
TABLE 2. X-ray diffraction powder pattern for the compound $\mathrm{Ca}_{4} \mathrm{Ti}_{3} \mathrm{O}_{10}\left(\mathrm{CuK} \alpha_{1}\right.$ radiation $)$

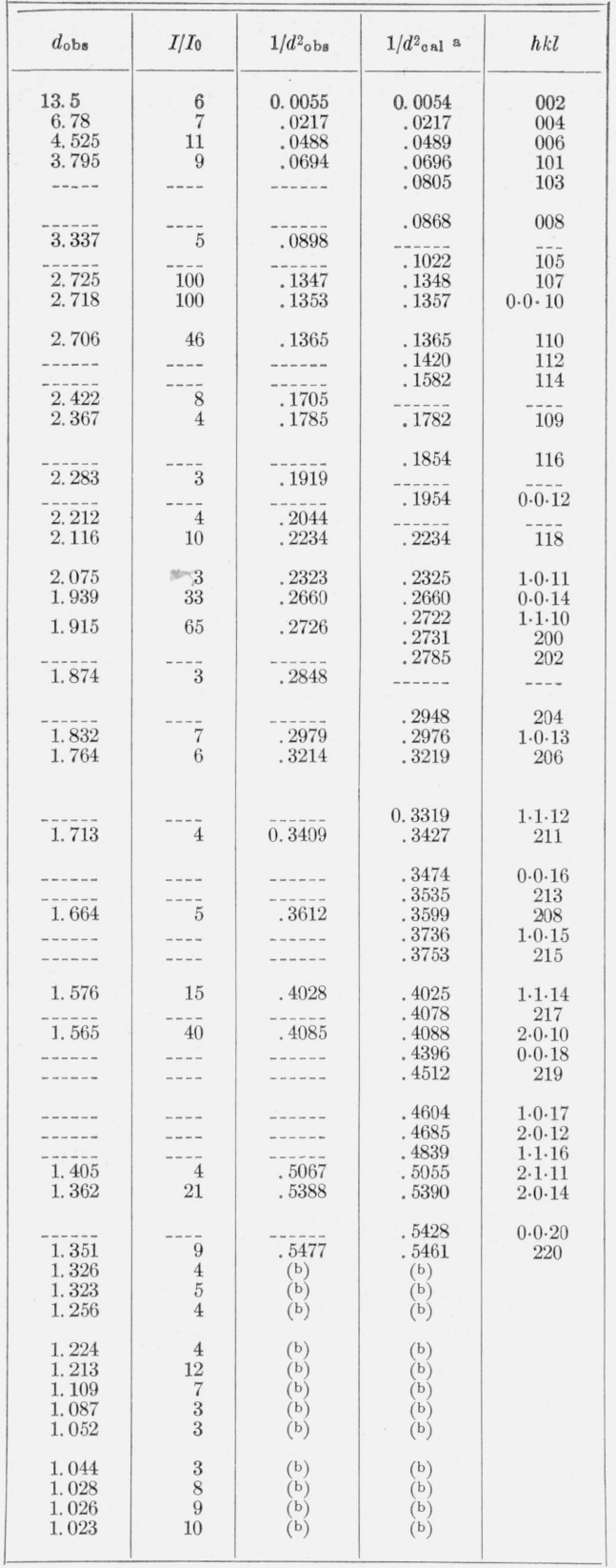

a The $1 / d^{2}$ values have been calculated on the basis of a tetragonal unit cell with $\mathrm{a}=3.827 \mathrm{~A}$ and $\mathrm{c}=27.147 \mathrm{~A}$

b Due to the very large unit cell, no attempt was made to index the rest of this pattern.

patterns can be almost completely accounted for on the basis of two tetragonal unit cells, there are still some very small peaks which cannot be indexed on this basis. It seems possible that these calciatitania compounds are not completely isostructural with the corresponding strontia-titania compounds. It is possible that these compounds have lower symmetry, just as $\mathrm{CaTiO}_{3}$ has a lower symmetry than $\mathrm{SrTiO}_{3}$.

DeVries, Roy, and Osborn [2] have published parts of X-ray diffraction patterns of a series of mixtures 


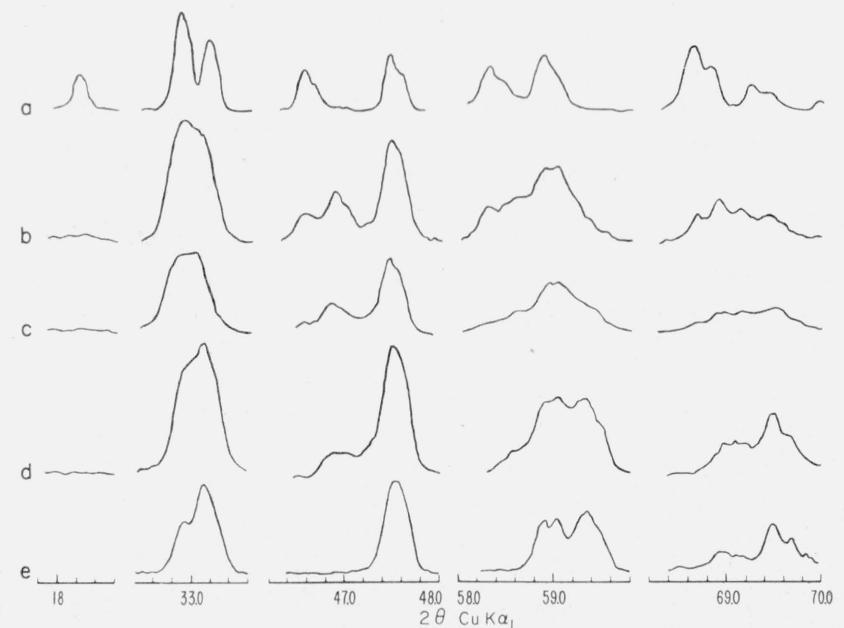

Figure 1. X-ray diffractometer patterns of a series of mixtures from $\mathrm{Ca}_{3} \mathrm{Ti}_{2} \mathrm{O}_{7}$ to $\mathrm{CaTiO}_{3}$ (after melting and quenching).

Taken from DeVries, Roy, and Osborn [2].

$a=51.29 / 48.71$ wt. $\% \mathrm{CaO} / \mathrm{TiO}_{2}\left(\mathrm{Ca}_{3} \mathrm{Ti}_{2} \mathrm{O}_{7}\right)$

$\mathrm{b}=48.65 / 51.35$ wt. $\% \mathrm{CaO} / \mathrm{TiO}$

$\mathrm{c}=46.00 / 54.00 \mathrm{wt} . \% \mathrm{CaO} / \mathrm{TiO}$

$\mathrm{d}=41.24 / 58.76$ wt. $\% \mathrm{CaO} / \mathrm{TiO}_{2}\left(\mathrm{CaTiO}_{3}\right)$
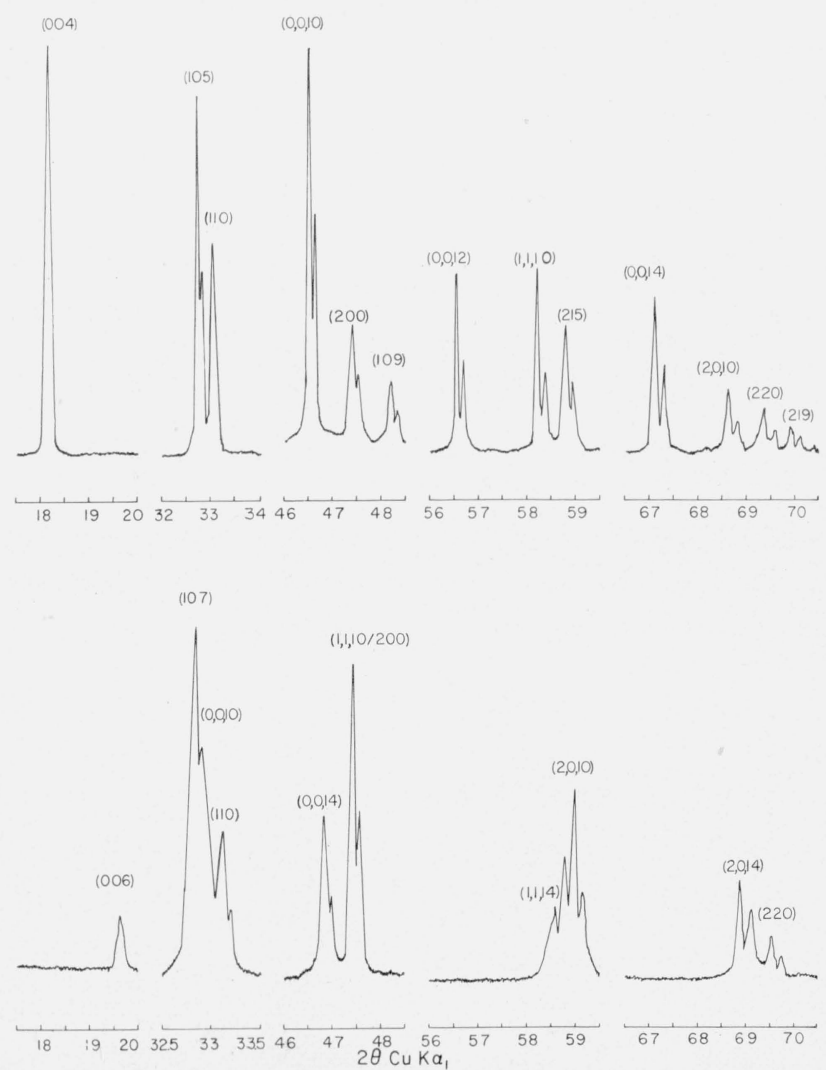

Figure 2. X-ray diffraction patterns, from the present work, of the two compounds $\mathrm{Ca}_{3} \mathrm{Ti}_{2} \mathrm{O}_{7}$ (above) and $\mathrm{Ca}_{4} \mathrm{Ti}_{3} \mathrm{O}_{10}$ (below) covering essentially the same part of the diffraction spectra as figure 1. from $\mathrm{Ca}_{3} \mathrm{Ti}_{2} \mathrm{O}_{7}$ to $\mathrm{Ca} \mathrm{TiO}_{3}$ after melting and quenching. Part $a$ (of fig. 3, ref. [2] reproduced here as fig. 1) represents a portion of the pattern of $\mathrm{Ca}_{3} \mathrm{Ti}_{2} \mathrm{O}_{7}$ and part $e$ that of $\mathrm{CaTiO}_{3}$. Figure 2 shows essentially the same portions of the $\mathrm{X}$-ray patterns of the two compounds $\mathrm{Ca}_{3} \mathrm{Ti}_{2} \mathrm{O}_{7}$ and $\mathrm{Ca}_{4} \mathrm{Ti}_{3} \mathrm{O}_{10}$, as found in the present work. Although all of the patterns in figure 1 are very poorly resolved it can be seen in part $b$ that there are three peaks in the region of 46 to $48^{\circ} 2 \theta$. The composition of this mixture is very close to $4 \mathrm{CaO}: 3 \mathrm{TiO}_{2}$ and this pattern represents the compound $\mathrm{Ca}_{4} \mathrm{Ti}_{3} \mathrm{O}_{10}$ with a small amount of $\mathrm{Ca}_{3} \mathrm{Ti}_{2} \mathrm{O}_{7}$. Parts $c$ and $d$ are mixtures of $\mathrm{CaTiO}_{3}$ and $\mathrm{Ca}_{4} \mathrm{Ti}_{3} \mathrm{O}_{10}$ and both show the center of the three peaks at $47^{\circ} 2 \theta$, while this peak is eliminated in part $a, \mathrm{Ca}_{3} \mathrm{Ti}_{2} \mathrm{O}_{7}$. These published $\mathrm{X}$-ray diagrams support the theory of an intermediate compound $\left(\mathrm{Ca}_{4} \mathrm{Ti}_{3} \mathrm{O}_{10}\right)$ much better than the theory of solid solution proposed by the authors of the published patterns.

\section{Experimental Procedures}

It might be thought possible that $\mathrm{Ca}_{4} \mathrm{Ti}_{3} \mathrm{O}_{10}$ is only a metastable compound having no true equilibrium position in the $\mathrm{CaO}-\mathrm{TiO}_{2}$ phase diagram. If such were the case, an equi-molar mixture of preformed $\mathrm{CaTiO}_{3}$ and $\mathrm{Ca}_{3} \mathrm{Ti}_{2} \mathrm{O}_{7}$ would not form the $\mathrm{Ca}_{4} \mathrm{Ti}_{3} \mathrm{O}_{10}$ phase upon heating. Such an equi-molar mixture was prepared, using the same raw materials as in the previous study (Coughanour, Roth, and DeProsse [1]). The specimen was heated in a conventional $\mathrm{Pt}$-wound quench furnace to $1,650^{\circ} \mathrm{C}$, held for $2 \mathrm{hr}$, and quenched in air. The compound $\mathrm{Ca}_{4} \mathrm{Ti}_{3} \mathrm{O}_{10}$ was the only product identified in this specimen. It must therefore be concluded that the compound $\mathrm{Ca}_{4} \mathrm{Ti}_{3} \mathrm{O}_{10}$ is the equilibrium product of the composition $4 \mathrm{CaO}: 3 \mathrm{TiO}_{2}$, at least at $1,650^{\circ} \mathrm{C}$.

From the data of Coughanour, Roth, and DeProsse [1] as well as that of DeVries, Roy, and Osborn [2], it can be seen that the compound $\mathrm{Ca}_{4} \mathrm{Ti}_{3}-$ $\mathrm{O}_{10}$ can not melt congruently. It must either dissociate before melting or else melt incongruently at a temperature somewhat higher than the incongruent melting point of $\mathrm{Ca}_{3} \mathrm{Ti}_{2} \mathrm{O}_{7}$, given in both papers as $1,750^{\circ} \mathrm{C}$.

Specimens with a calcia-titania ratio of $4: 3$ were pressed into pellets, calcined in a conventional $\mathrm{Pt}$ wound furnace at $1,250^{\circ} \mathrm{C}$, ground, repressed, and reheated to $1,600^{\circ} \mathrm{C}$ and slow-cooled. They showed only the compound $\mathrm{Ca}_{4} \mathrm{Ti}_{3} \mathrm{O}_{10}$. Specimens were then ground and placed in a $\mathrm{Pt}$ envelope, heated in the Pt-wound quench furnace, and quenched into water from temperatures of $1,500^{\circ} \mathrm{C}, 1,550^{\circ} \mathrm{C}, 1,600^{\circ} \mathrm{C}$ and $1,650^{\circ} \mathrm{C}$. All of these quenched specimens still showed only the compound $\mathrm{Ca}_{4} \mathrm{Ti}_{3} \mathrm{O}_{10}$. Specimens were then heated and quenched in a graphite susceptor induction furnace, from temperatures of $1,700^{\circ} \mathrm{C}$ and $1,725^{\circ} \mathrm{C}$. These two specimens also showed only the compound $\mathrm{Ca}_{4} \mathrm{Ti}_{3} \mathrm{O}_{10}$. One more specimen was placed in a smooth $\mathrm{Pt}$ tube, so that the temperature could be read more precisely with an optical pyrometer, heated to $1,745^{\circ} \mathrm{C}$ and quenched. This specimen still showed only $\mathrm{Ca}_{4} \mathrm{Ti}_{3}-$ $\mathrm{O}_{10}$. As the reported solidus for $\mathrm{Ca}_{3} \mathrm{Ti}_{2} \mathrm{O}_{7}$ is $1,750^{\circ}$ 


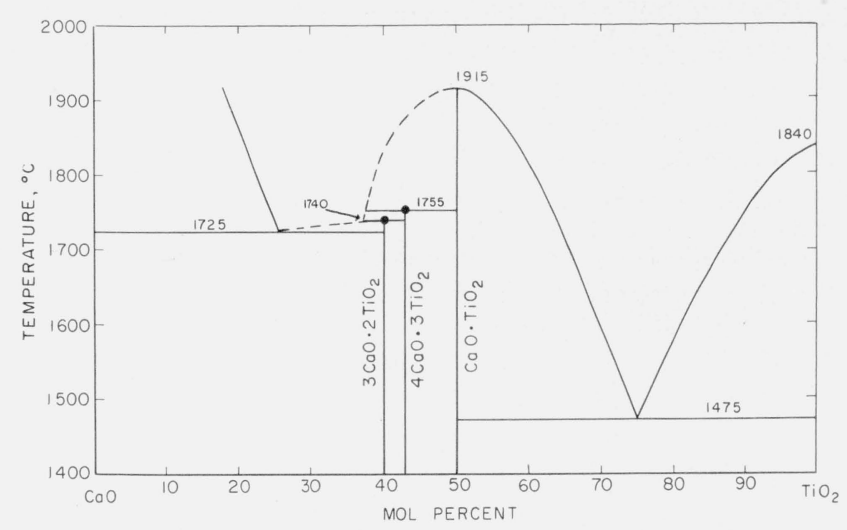

Figure 3. Revised phase equilibrium diagram of the system $\mathrm{CaO}-\mathrm{TiO}_{2}$, showing the compound $\mathrm{Ca}_{3} \mathrm{Ti}_{2} \mathrm{O}_{7}$ melting incongruently at $1,740^{\circ} \mathrm{C}$ and the compound $\mathrm{Ca}_{4} \mathrm{Ti}_{3} \mathrm{O}_{10}$ melting incongruently at $1,755^{\circ} \mathrm{C}$.

(After Coughanour, Roth, and DeProsse [1]).

Solidus temperatures determined in the present study.

$\mathrm{C}$, it must be assumed that $\mathrm{Ca}_{4} \mathrm{Ti}_{3} \mathrm{O}_{10}$ either does not dissociate to two solids, or that such dissociation cannot be quenched.

In order to check the solidus temperatures of the two compounds $\mathrm{Ca}_{3} \mathrm{Ti}_{2} \mathrm{O}_{7}$ and $\mathrm{Ca}_{4} \mathrm{Ti}_{3} \mathrm{O}_{10}$, fragments of the two materials, previously heated to $1,650^{\circ} \mathrm{C}$ for $2 \mathrm{hr}$, were set side by side on an iridium button in the graphite induction furnace. The $\mathrm{Ca}_{3} \mathrm{Ti}_{2} \mathrm{O}_{7}$ specimen definitely began melting before the $\mathrm{Ca}_{4} \mathrm{Ti}_{3} \mathrm{O}_{10}$ specimen. However, the fluid liquid quickly spread over the iridium button, obscuring the results of melting of the second specimen. As it appeared that the iridium button was hotter than the inside of the graphite crucible, a new experiment was performed utilizing only an iridium crucible with an iridium button inside. Using a flat button and a cover on the crucible and sighting through a hole in the cover, perfect black-body conditions were obtained and the specimen could not be seen. By utilizing a concave button and no cover, the specimen could be watched during the whole experiment. The temperature of the solid specimen at beginning of melting appeared $25^{\circ}$ to $30^{\circ} \mathrm{C}$ cooler than the true temperature, but the liquid formed appeared to show the true temperature. The solidus temperature for $\mathrm{Ca}_{3} \mathrm{Ti}_{2} \mathrm{O}_{7}$ was found to be $1,740^{\circ} \mathrm{C}$ and that of $\mathrm{Ca}_{4} \mathrm{Ti}_{3} \mathrm{O}_{10}$ was $1,755^{\circ} \mathrm{C}$. These results were rechecked by again heating fragments in the iridium crucible using a flat button and the crucible cover. The $\mathrm{Ca}_{3} \mathrm{Ti}_{2} \mathrm{O}_{7}$ specimen when heated to $1,740^{\circ} \mathrm{C}$ showed a rounding of the corners and a small amount of crystal growth on the iridium button. The $\mathrm{Ca}_{4} \mathrm{Ti}_{3} \mathrm{O}_{10}$ specimen showed no sign of melting at this temperature but did show some melting when heated to $1,755^{\circ} \mathrm{C}$.

These measurements have been used to revise the phase diagram of the binary system $\mathrm{CaO}-\mathrm{TiO}_{2}$ first proposed by Coughanour, Roth, and DeProsse [1]. ${ }^{3}$ The revised diagram is shown in figure 3 .

\section{Summary}

The compound $\mathrm{Ca}_{4} \mathrm{Ti}_{3} \mathrm{O}_{10}$ has been shown to exist as a stable phase in the system $\mathrm{CaO}-\mathrm{TiO}_{2}$. Both compounds are pseudo-tetragonal with only a few weak lines indicating a departure from tetragonality. The $c$-axis $=19.505 \mathrm{~A}$ for $\mathrm{Ca}_{3} \mathrm{Ti}_{2} \mathrm{O}_{7}$ and $27.147 \mathrm{~A}$ for $\mathrm{Ca}_{4} \mathrm{Ti}_{3} \mathrm{O}_{10}$. The dimensions indicate that $\mathrm{Ca}_{3} \mathrm{Ti}_{2} \mathrm{O}_{7}$ has double perovskite layers interleaved with $\mathrm{CaO}$, while $\mathrm{Ca}_{4} \mathrm{Ti}_{3} \mathrm{O}_{10}$ has triple perovskite layers interleaved with $\mathrm{CaO}$. The new compound, $\mathrm{Ca}_{4} \mathrm{Ti}_{3} \mathrm{O}_{10}$, has been found to melt incongruently at about $1,755^{\circ} \mathrm{C}$, while the incongruent melting point of $\mathrm{Ca}_{3} \mathrm{Ti}_{2} \mathrm{O}_{7}$ has been shown to be about $1,740^{\circ} \mathrm{C}$. The revised phase diagram for the system $\mathrm{CaO}-\mathrm{TiO}_{2}$ is presented.

The assistance of Charles R. Drew in preparing and heating the specimens and of Sylvanus $\mathrm{F}$. Holley for operating the induction furnace is gratefully acknowledged.

\section{References}

[1] L. W. Coughanour, R. S. Roth, and V. A. DeProsse, J. Research NBS 52, 37 (1954) RP2470.

[2] R. C. DeVries, R. Roy, and E. F. Osborn, J. Phys. Chem. 58, 1069 (1954).

[3] H. G. Fisk, Jr., J. Am. Ceram. Soc. 34, 9 (1951).

[4] S. N. Ruddlesden and P. Popper, Acta Cryst. 11, 54 (1958).

[5] S. N. Ruddlesden and P. Popper, Acta Cryst. 10, 538 (1957).

3 The two previously published diagrams of Coughanour et al. [1] and DeVries et al. [2] disagree on the temperatures of the melting point of $\mathrm{CaTiO}_{3}\left(1,915^{\circ} \mathrm{C}\right.$ and $1,970^{\circ} \mathrm{C}$ ) and on the temperature of the eutectic between $\mathrm{CaO}$ and $\mathrm{Ca}_{3} \mathrm{Ti}_{2} \mathrm{O}_{7}$ $\left(1,725^{\circ} \mathrm{C}\right.$ and $\left.1,695^{\circ} \mathrm{C}\right)$. No attempt has been made in the present study to $\left(1,725^{\circ} \mathrm{C}\right.$ and $\left.1,695^{\circ} \mathrm{C}\right)$. No atte
reconcile these two discrepancies.

Washington, August 4, 1958. 